\section{Reading the history of venereal diseases in the city: Venereal disease from Surabaya, 19th-20th century}

\author{
Moordiati \\ Department of History, Faculty of \\ Humanites, Airlangga University; \\ Department of History, Faculty of \\ Humanities, Gadjah Mada University \\ Surabaya, Indonesia
}

\begin{abstract}
This article aims to explore about venereal diseases that occurred in the city of Surabaya throughout the nineteenth to the twentieth century. Not much is known about what actually happened with the presence of venereal disease in the city of Surabaya throughout this period. Some existing sources are still always connected if the presence of venereal disease is more caused by prostitution activities as alleged during this time. Though it does not rule out the possibility if the disease is also caused by the consequences of others. This is presumably that became one of the reasons of this article to see if there are any reasons or other reasons to why the venereal disease can exist in Surabaya. Therefore the use of many sources (primary or secondary) is very important in this article to compare and differentiate between venereal diseases in the city of Surabaya and other cities.
\end{abstract}

\section{Introduction}

Venereal disease can be categorized as an infectious disease according to the medical community (health) can be caused by bacteria or viruses known as viral venerisch granuloom (granuloma venerum) now known as a virus or bacteria or Donovanosisinguinal granuloma. ${ }^{1}$ By Gani A. Jaelani (2013) it was also revealed if there were various bacteria or viruses that were considered to be the cause of the emergence of venereal diseases. First, is a virus or bacteria that causes druiper, but is not present in people with syphillis. Second, the virus that is the cause of druiper but not in the weeke spanker sufferers, namely venereal disease that is only genital, but also attacks the entire body. ${ }^{2}$ These viruses which, when they are contagious in a person's body, will become hot, then burn and the peak will feel itching, especially in the urinary tract. ${ }^{3}$ Even so apparently still very rare from the population in the Dutch East Indies who knew the existence and causes of this disease well, even when the disease had "arrived" in the archipelago (Dutch East Indies) in the 1500s. Most of the population seems to be even more confident with the story that already existed at that time if venereal disease or what they commonly know with lion's body (radja Singa) is a disease caused by the result of a relationship or contact with a woman who is affected or suffering from venereal disease. . $^{1,3,4}$

So it's not unusual for this belief to remain a lasting construction.until now, moreover coupled with the existence of a large number of evidence that shows if there is indeed the involvement of women who have been "agents" in the process of spreading sexually transmitted diseases. Such as in several sources of reports belonging to the Resident on Java in the period from the mid-nineteenth century to the beginning of the twentieth century, namely as in the report belonging to Resident Bagelen in 1843an. Although they did not directly mention the involvement of women in the spread of venereal disease in their area, in reality, what did the residents do by establishing brothels (brothels) clearly indicates that their existence as "immoral women" did exist at that time.in fact, it seems even deliberately protected by the government (state). ${ }^{2}$ Other evidence is also revealed at least from the results of the Kedu Resident's report in the 1830 s.It was revealed in the report that many women were found to have worked on plantations during this period, certainly not just as laborers (workers) in plantations as they have been told so far, but also as "entertainers" for workers (laborers) especially men who existed or lived on plantations owned by the colonial government at the time..$^{5-8}$ In fact, often not even behind the colonial and local soldiers (soldiers) who are members of the Djayengsekar warrior group and of course the plantation foreman. ${ }^{9-10}$ Presumably this has become commonplace in the plantation area at the time, and it might even be said that it would find the same thing in most of the plantation area. Included in plantations in the Jepara Residency area and in the Surakarta Residency. ${ }^{2,11}$

Even so, it seems that there are others who still consider if there are other things besides what has become the evidence above. It is not strange if this matter finally invites different opinions from some circles such as from the opinion of HF Tillema and Dr. Soetomo. Both view that the cause of venereal disease is certainly no longer just a matter of "mistakes" from women's involvement. Do not rule out the possibility if venereal disease is also a disease that can
Correspondence: Moordiati, Department of History, Faculty of Humanites Airlangga University, Campus B, Jln. Dharmawangsa Dalam Surabaya, 60286, Indonesia.

Tel.: $08155170057-083843103322$

E-mail: diatigf@yahoo.com

ilmusejarah@fib.unair.ac.id

Key words: venereal disease, Surabaya, prostitution, city.

Conflict of interest: the author declares no potential conflict of interest.

Received for publication: 1 February 2019. Accepted for publication: 13 february 2019.

This work is licensed under a Creative Commons Attribution-NonCommercial 4.0 International License (CC BY-NC 4.0).

(C) Copyright Moordiati, 2019

Licensee PAGEPress, Italy

Dermatology Reports 2019; 11(s1):8047 doi:10.4081/dr.2019.8047

come or come from a good community group, such as merchants, priyayis to servants, babu or drivers who work for foreigners. $^{2}$ It seems that as a moralist, Soetomo wanted to reveal facts and other evidence from what had been there so far that venereal disease was a representation or consequence of a woman's error product of a venereal disease. This is also what HF Tillema does when it comes to seeing issues of venereal disease from different perspectives. Tillema agrees with what was thought by Dr. Soetomo at that time that there were other things that could cause the emergence of venereal disease, besides only women. Therefore, Tillema assumes that it does not rule out the possibility that venereal disease is also related to hygiene problems (hyginietas). ${ }^{12}$ This is certainly not because of Tillema's background as a pharmacist, it seems Tillema was also keen enough to observe and see several cases of venereal disease in several cities in Java, especially in several port cities throughout the 19th century. It is very surprising if it turns out that there are different results with cases of venereal disease among the cities with the attention of HF Tillema at that time. Starting from cities that fall into the category of port cities to big cities like the City of Bandung. ${ }^{2,13,14}$ It is also one reason for this article to prove what happened in Surabaya. Why can venereal disease exist in the city of Surabaya at that time? Is the presence of this disease as expected? Or is there even another thing or condition that caused the emergence of an "outbreak" of venereal disease in the city of Surabaya throughout this period. 


\section{$W A B A H$ venereal disease in Surabaya}

News the presence of venereal disease in the city of Surabaya is no longer just a mere guess or issue. This evidence was revealed at least from what had been the news in one of the health magazines, Geneeskundige TijdschriftNederlandsch Indie (GTNI) published in 1934.In the contents of the news revealed that the City of Surabaya is one of the cities in Java that has a number or number of sufferers of venereal disease (in this case syphilis ) is quite large among several other cities in Java such as Batavia (Jakarta), Bogor, Malang, Surakarta, (Solo), namely 712 people in 1931 and 532 people in $1932 .{ }^{14,15}$

Not only once, news or news about the existence of venereal disease in the City of Surabaya.Previously there had also been a report from Governor General PJ Rohtenbuhler regarding the presence of venereal disease in the City of Surabaya, even if it was considered as the earliest report at that time. ${ }^{16}$ From his report, Rohtenbuhler only mentioned that there were "infectious diseases" among sailors who came to the city of Surabaya at that time. Rohtenbuhler is not even explained clearly whether there is a similarity between "infectious disease" and venereal disease. Only in the report was it mentioned if many sailors then died after previously visiting (visiting) a place (kampung) in Surabaya City. ${ }^{16}$ Specification the same who later became news in old newspapers, publications Bintang Soerabaia 1883. Disclosed in newspapers is about complaints from opsier ship because they have been exposed to a disease while in a house in Kampung Nyamplungan Surabaya.The ship optioners felt that before they were still healthy (not sick) when they went to the village.But why suddenly they (sailors) finally have to suffer from this dirty "infection" disease. 17,18

Such a situation seems to be still the subject of conversation and reporting in the same newspaper (Bintang Soerabaia) in 1884. According to what was reported in this newspaper, there were allegations that in Djagalan village there was also a "plague" of venereal diseases as in Kampoeng Nyamplungan. Although it was not explained in the newspaper, anyone who was affected or suffered from venereal disease, apparently this rumor or news had made residents around the village uneasy. Until finally the residents had to ask for police assistance to inspect the village. ${ }^{19}$ This same anxiety is also felt by Dr. Soetopo when he was in the 1950s still found the number of people with venereal disease among the population of Surabaya City increased to very high. War and postwar insecurity are considered to have been the cause of sporadic disease development in Surabaya, including venereal disease. Even stated by Dr. W.J. Hohmann if the possibility of this also related to the existence of the habist of inhabitants of this diving taboo to express it. ${ }^{15,20,21}$ It is not surprising if finally find no less than 2900 sufferers of venereal disease in Surabaya at that time. This amount is the result of their visit at several hospitals as well as the Surabaya City health treatment center. Of this amount, $20 \%$ or about 2365 people turned out to be sufferers of "active" venereal disease or patients with venereal disease in an infectious state. ${ }^{21}$ Not only this, it turns out that cases of "active" venereal disease (venereal venereal disease) are also found in some groups of people who have a military background. This information was taken from the results of research conducted by the Surabaya City Center for Investigation and Eradication of Disease (LPPPK). Unexpectedly, the percentage of patients with syphilis is latent in members of the policequite large, which is $78 \%$. While for members of the Army there are $33 \% .{ }^{21}$ Even the most surprising was the discovery of venereal disease in pregnant women between 11-16\%.This examinations at the BKIA (maternal and child health centers) in Surabaya. ${ }^{15}$ In fact, this also had the opportunity to become a material for reporting if more than 10 pregnant women were found out of 100 people who came to the BKIA because they were infected or were positively suffering from venereal disease (serologically positive syphilliis). ${ }^{13,21,22}$

\section{Revealing the secret veil of the city}

The fact that there will be a large number of sufferers of venereal disease in the city of Surabaya during the 19 until 20 century apparently even more raises also various assumptions, reactions and big question marks about what actually happened with the emergence of this disease in the city of Surabaya. Moreover, a lot of things that were unexpected beforehand with the existence of venereal disease here, such as whether this disease originated from the city of Surabaya or was actually brought by outsiders (migrants) who came to the city of Surabaya.

The initial hypothesis that has been built is more to say if the existence of this disease in the city of Surabaya is nothing more than the number of women who become prostitutes in the city of Surabaya. But it is not like prostitutes in general, they (women) actually come from poor women who do not have a permanent job in the city of Surabaya or in the source PJ Rohtenbuhler is called a female homeless. ${ }^{16}$ It was alleged that they were eventually "gathered/recruited" in a shelter (brothel) at very cheap prices in the village of Bandaran Surabaya. ${ }^{16}$ This village is actually very inappropriate to say as a place to live. The entrance to this village must first pass through the swamps where the water is very smelly and many mosquitoes. There are no good buildings or houses, other than dilapidated bamboo huts. In fact there is no one else in this village other than people who are only looking for "fun" at a low cost. ${ }^{16}$ Even though it was very inappropriate, there were apparently many who visited this village, especially those of the new seafaring ospiers from ships on the port .It is very ironic, with such conditions there is certainly no guarantee if their level of cleanliness will be maintained properly. Moreover, there are no reports or stories so far if there is supervision or handling of health from the government to them. The government only had time to issue regulations (especially for brothel owners) in 1874 which contained the first, if a woman was seen with syphillis infection/infectious disease, then she would be issued with a card and their position was in the serial number. Second, if possible all women will be examined once a week. Third, with the exception of Ronggeng or dance girls, all women must join or join as much as possible. Fourth, if there are a number of women (5 people) they are considered to have entered brothels. Fifth, the government must also ensure the separation of young prostitutes with older prostitutes. ${ }^{16}$

Seeing the regulations issued, it seems that almost all brothel owners enforce this regulation, especially in the effort to maintain the health of the "workforce". They tend to be left alone, so it's no wonder when it is revealed that an infectious disease comes from them. As in the news of Bintang Soerabaia 1883:

"At the house of the pimp, dark njonjah $\mathrm{S}$. in the village of Nyamploengan, with a lot of content, there are still roads that are bad, like the cooing of the new baroque, the dark soendel has been trapped by the toean odj, because there is also a boat option. he got a sick person in his house, he was not able to get a person because he did not have a sick person because he did not have a place in the hospital. He could not be made clean in the hospital center, so that each other was clean and did not make matroos hurt, presumably if Matroos got it a 
painkiller from his weakness, what does he do not fulfill" (Bintang Soerabaia, 1 October 1883). ${ }^{17}$

"Di rumah germo gelap njonjah S. di kampung Nyamploengan isi banjak sadja prampoean njang berdjalan djahat, seperti koetika boelan njang baroe-baroe ini soendel gelap sudah di tangkep oleh toeantoean odj, sebab ada keloechtnya opsier kapal juga kena penjakit di roemahnya njonja $\mathrm{S}$. ia pigisana orang tidak bisa kena penjakit sebab itoe perempoean njang ada di tempat njonjah $\mathrm{S}$ tidak taoe di bikin bersih di roemah sakit Girikan, biar satoe sama lain bersih tdak bikin matroosmatroos ssakit, kiranya kalo matroos kena itoe penjakit dari roemahnya njonja $\mathrm{s}$, apa tidak menjoesahkan" (Bintang Soerabaia, 1 Oktober 1883). ${ }^{17}$

Not only once is this news, almost the news found at that time always talks about the lack of cleaning for these women. Even before it was never revealed before about what was given to maintain their health, such as the type of vaccine or treatment used. It's just that some sources say that they will always be taken to a hospital located in Pegirian. In the hospital, they will be separated first with mental disorders and leprosy (leprosy), there is no special therapy, only if they are very dangerous usually will be separated from the hospital and taken to a place outside the city of Surabaya. ${ }^{16}$ This hypothesis may still be convinced that the presence of venereal disease in the city of Surabaya is due to the existence of prostitution. Even though it could also be related to the issue of the development of the city of Surabaya itself which at that time grew into a port city and industry.

\section{Conclusions}

The existence of venereal disease does not have to or should not be related to the existence of prostitution. Many things make this disease appear, especially in big cities like Jakarta, Semarang or Surabaya. The development of the city and the intervention of handling health are things that can be used to see the development of disease in a city.

\section{References}

1. Boomgaard P. Syphilis, gonorrhea, leprosy and yaws in the Indonesian archipielago, 1500-1950. MANUSYA: J Humanities, Special Issue 2007;14:2041.

2. Jaelani GA. Penyakit Kelamin di Jawa 1812-1942. Bandung:Syabas Books; 2013.

3. NN. Mas'alah "P", Djakarta: Kementrian Sosial Republik Indonesia; 1950.

4. Crawurd J. History of Indian Archipelago. Edinburg;1820.

5. Suroyo AMD. Eksploitasi Kolonial Abad XIX; Tanam Paksa di Keresidenan Kedu, 1800-1890. Yogyakarta: Yayasan Untuk Indonesia; 2000.

6. Bleeker PK.", "Fragmenten eener Reis Over Java"",Tijdscrijft Nederlandsch Indie (TNI)1850. Groningen: Tweede Deel; 1850 .

7. Stibbe DG. Encyclopaedie van Nederlandsch Indie. Leidenl; EJ Brill; 1918.

8. Hesselink L. Healers on the Colonial Market: Native Doctors and Midwives in the Dutch East indies. Brill: KITLV; 2002.

9. Kedoe Archive no 5/22; Verbaal, 29
August 1855

10. Algemeene verslag Kedoe,no.1-9 (1827-1929).

11. Suhartono, Apanage dan Bekel;Perubahan Sosial di Pedesaan di Surakarta, $1830-1920$ Yogyakarta:Tiara Wacana;1991.p 39-45

12. Tillema HF. "Geslachtsziekten", Kromoblanda;Over't vraagstuk van'het wonen in kromo's groote land, s'Gravenhage; 1920-1921. p 21.

13. NN. Challenges and Answers ;25 years Building Surabaya Health Service Research and Development Center. Surabaya: P4K; 1974.

14. Palte W \& PM Van. Syphilis van het Zenuwstelsel bij Aziaten in Nederlandsch Indie, Geneeskundige Tijdschrift Nederlandsch Indie (GTNI) uitgegeven door de Vereeniging tot Bevordering der Geneeskundige Wetenschappen in Netherlandsche Indie, deel 74, afl 17;14 August 1934. p 1039.

15. NN. Sejarah Kesehatan Nasional Indonesia. Jilid 2. Departemen Kesehatan Republik Indonesia; 1980. p 62.

16. A Faber GH von. Oud Soerabaia,De Geschiedenis van Indie's eerstecoopstaad van de oudste tijden tot de instelling van de Gemeenterad (1906) ,uitgegeven door de Gemente Soerabaia ter gelegenheid van haar zilveren jubileum op;April 1;1931. p 242-245.

17. Bintang Soerabaia; 1883.

18. Moordiati. City Society in Surabaya History, 1930-1960, in Freek Colombijn et al, The old City of the new City;History of Cities in Indonesia. Yogyakarta: Ombak; 2005. p 306.

19. Bintang Soerabaia; 1884.

20. Pawarta Soerabaia;1950.

21. Surabaya Post;1953.

22. Soera Poebliek;1926 